\title{
Cutaneous Melanoma pN1 TNM Finding v7
}

National Cancer Institute

\section{Source}

National Cancer Institute. Cutaneous Melanoma pN1 TNM Finding v7. NCI Thesaurus.

Code $C 88387$.

Cutaneous melanoma with metastasis in one regional lymph node. (from AJCC 7th Ed.) 